\title{
Correction to: Transcriptomics of manually isolated Amborella trichopoda egg apparatus cells
}

\author{
María Flores-Tornero $^{1} \cdot$ Sebastian Proost ${ }^{2,5} \cdot$ Marek Mutwil $^{2,3} \cdot$ Charles P. Scutt $^{4} \cdot$ Thomas Dresselhaus $^{1}$. \\ Stefanie Sprunck ${ }^{1}$
}

Published online: 25 February 2019

(c) The Author(s) 2019

\section{Correction to: Plant Reproduction https://doi.org/10.1007/s00497-019-00361-0}

The article Transcriptomics of manually isolated Amborella trichopoda egg apparatus cells, written by María FloresTornero, Sebastian Proost, Marek Mutwil, Charles P. Scutt, Thomas Dresselhaus, Stefanie Sprunck, was originally published electronically on the publisher's internet portal (currently SpringerLink) on 1 February 2019 without open access. With the author(s)' decision to opt for Open Choice, the copyright of the article changed on 22 February 2019 to (C) The Author(s) 2019 and the article is forthwith distributed under the terms of the Creative Commons Attribution 4.0 International License (http://creativecommons.org/licenses/ by/4.0/), which permits use, duplication, adaptation, distribution and reproduction in any medium or format, as long as you give appropriate credit to the original author(s) and the source, provide a link to the Creative Commons license and indicate if changes were made.

The original article has been corrected.

The original article can be found online at https://doi.org/10.1007/ s00497-019-00361-0.

Stefanie Sprunck

stefanie.sprunck@ur.de

1 Cell Biology and Plant Biochemistry, Biochemie-Zentrum Regensburg, University of Regensburg, Universitätsstrasse 31, 93053 Regensburg, Germany

2 Max-Planck Institute for Molecular Plant Physiology, Am Muehlenberg 1, 14476 Potsdam, Germany

3 School of Biological Sciences, Nanyang Technological University, 60 Nanyang Drive, Singapore 637551, Singapore

4 Laboratoire Reproduction et Développement des Plantes, École Normale Supérieure de Lyon, Université Claude Bernard Lyon 1, CNRS, INRA, Université de Lyon, Lyon, France

5 Present Address: Laboratory of Molecular Bacteriology (Rega Institute), KU Leuven, Louvain, Belgium
Open Access This article is distributed under the terms of the Creative Commons Attribution 4.0 International License (http://creativeco mmons.org/licenses/by/4.0/), which permits use, duplication, adaptation, distribution and reproduction in any medium or format, as long as you give appropriate credit to the original author(s) and the source, provide a link to the Creative Commons license, and indicate if changes were made.

Publisher's Note Springer Nature remains neutral with regard to jurisdictional claims in published maps and institutional affiliations. 